\title{
COMPLEXITY OF THE EFFECTS OF CROSS BORDER MERGER ON INTERNAL MARKET UNDER THE BOTH COMPANY LAW AND COMPETITION LAW
}

\section{Charlotte ENE}

University of Economic Studies Bucharest, Law Department, Bucharest, Romania, e-mail: enecharlotte@gmail.com

\begin{tabular}{|c|c|}
\hline Abstract & $\begin{array}{l}\text { The purpose of this paper is to provide an insight into the legal regime of the effect s of cross-border } \\
\text { merger on internal market assessed from Company Law and Company law provisions. } \\
\text { On the other hand merger may be analyzed as abuse of market power which affect European trade, } \\
\text { qualified as a dominant position by the European Commission and the European Union Court of } \\
\text { Justice. Therefore, competition provisions purpose also to remove the barriers to European internal } \\
\text { market arising from actions of powerful of single undertakings which enjoy a dominant position in a } \\
\text { particular market for good and services. However, the new European legislation would make it easier } \\
\text { and much cheaper for undertakings (companies with share capital) to merge with enterprises in other } \\
\text { Member States. }\end{array}$ \\
\hline
\end{tabular}

Key words:

Undertakings, crossborder merger, competition law, abuse, dominant position, internal market.

JEL Codes: K33

\section{Overview of the issues}

Before the enacted the Directive 2005/56/EC of the European Parliament and of the Council the crossborder mergers have been rare within European Internal Market taken into account the serious uncertainties concerning the possibility of merging two (or more) undertakings subject to different Member States' legal systems, the procedural norms and other disposition regarding merger.(Schindler, 2006)

That status quo was dramatically changed based both on European secondary legislation and case law, which create a simple, clear and easily applicable legal framework of cross-border mergers.

Also, under the conditions of late global crisis, become very important to strengthen business activities at European level by cross-border mergers in order to face global competition

From other point of view, the provisions regarding cross-border merger is of crucial importance to the free movement of persons and capital across European Internal Market, and to enhance the integration. (Communication of the Commission, 1999).

However, taking into account the effect to the competition, the merger process determines a concentration of economic power, a dominant position on the market of the companies involved.

Therefore, it has to maintain a balance between company law and competition law provision.
2. Merger is a legal concept provided by competition law.

Competition policy has now become one of the most developed policies of the Community, based on the fundamental principle of undistorted competition in the internal market set out in Article 3 (1) (b) TFEU.

Furthermore, several analytical provisions detail that principle as Articles 101-106 (ex Articles 81-86 of the EC Treaty), and secondary legislation, Council Regulation (EC) No 139/2004 of 20 January 2004 on the control of concentrations between undertakings (the EC Merger Regulation - ECMR) in order to ensure that private or public undertakings do not adopt concerted practices or do not abuse their dominant position resulting in distortive effects on the internal market.

The most relevant provisions of EU competition law Article 101 (ex Art.81) and Article 102 (ex Art.82) TFEU referring to unfair business practices intend to promote business efficiency, to protect consumers, and to protect small and medium-sized enterprises from restrictive practices and the abuse of market power.

In general terms, Article 101 TFEU prohibits agreements between undertakings (meaning all kind of entities carries on the economic activities regardless of the legal status of the entity and the way in which it is financed Case C-41/90, Höfner and Elser) which prevent, restrict or distort competition within the internal market and affect trade between Member States. Among the possible infringements of these provisions, 
market sharing and price-fixing represent the two most damaging restrictions of competition.

Article 102 TFEU provides that any abuse by a dominant undertaking in the internal market shall be prohibited as incompatible with the internal market, affecting trade between Member States.

The Lisbon Treaty does not contain express provisions referring to the mergers. Although both Article 102 and Article 101 TFEU have been used as a means of controlling mergers, their usefulness in this context has now been to a large extent overtaken by the Merger Control Regulation.

However, mergers which do not fall within the purpose of the regulation may still breach those articles. (Berry, Hargreaves, 2007)

In 1989 the European Union Council adopted a long-standing Commission proposal for a Regulation on the control of concentrations of undertakings: Regulation no.4064/89. Subsequently this regulation has been replaced by the EC Merger Regulation 139/2004 (ECMR) which provides that the concept of concentration implies mergers, acquisitions and "full function" joint ventures. Thus, a transaction represent a concentration when it involves "a lasting change in the control of the undertakings concerned and therefore in the structure of the market."(Recital 20 ECMR)

According to the Articles 1(2) and 1(3) of the Regulation a concentration have a community dimension when the participating undertaking meet specified thresholds of turnover. In this case is applicable the principle of the "one-stop shop" whereby concentrations falling within the regulation requirements have to be notified only to the European Commission, thus preventing the multiple filings in different Member States.

Under Article 9 the concentration will be referred to the authority of the Member State which represents a "distinct market" meaning the market where the competition was significantly affected. Member States also may request the Commission to examine a concentration affecting trade between Member States (Article 22 of regulation).

Moreover, the parties themselves can request by reasoned submission prior to notification, a referral to the Commission where the concentration is subject of the review under the national competition law of at least 3 Member States or significantly affects competition in a market within a Member State.

The Member State concerned has 15 days to express their agreement or disagreement with referral. Under Article 21(4) of the regulation, Member States may take appropriate measures to protect other legitimate interests than those stipulated by regulation.

The Court of Justice of the European Union (CJEU) applied for the first time the provisions of the Article 102
TFEU to a merger occurred in Case 6/72, Europemballage Corp. and Continental Can Co. Inc. v. Commission. ECJ ruled that a merger is considered to fall within the definition of a concentration when the merged dominant undertakings eliminate competition in relevant market.

The economic concentration could be under specific circumstances assessed as an abuse of a dominant position.

Firstly, in Case 27/76 United Brands v. Commission, the CJEU defined dominant position as a "position of economic strength enjoyed by an undertaking which enables it to prevent effective competition being maintained on the relevant market by giving it the power to behave to an appreciable extent independently of its competitors, customers, and ultimately, of its consumers."

Dominance has to be examined in relation to the key factors of the relevant market, namely the relevant product market and the geographic market. (Horspool, Humphreys, 2006)

Once the relevant market has been identified, it has to analyze whether the undertaking occupies a dominant position in that market, taking into account the market share controlled by that undertaking, which has to be substantial.

Secondly, CJEU established in Case 85/76 Hoffmann-La Roche, that abuse of a dominant position consists in practices of dominant undertaking which affect the structure of the relevant market because the competition become weakened or is reduced. In summary, there are two categories of abuses: anticompetitive abuse (which exclude competitor from the relevant market by reducing competition) and exploitative abuses (dominant undertaking exploits its market power). (Horspool, Humphreys, 2006)

In practice, merger represents one of the main ways of settled economic concentration in view of the competition provisions. (Ene, 2009)

From this point of view, merger represents the union of two or more independent businesses into one in order to increase economic profitability and efficiency; and there are several types such as,

- merger by fusion occurs when two or more independent undertakings to unite in a new enterprise and cease to exist as separate businesses;

- merger by absorption occurs when a undertaking is embedded by another which preserves its legal capacity, while the first cease to exist as a legal entity;

- de facto merger is a combination of two or more independent undertakings creating a group which acts as a single business. All those forms of merger operations may generate a concentration with a Community dimension. 
In order to determine the impact of a concentration on competition in the common market, it is appropriate to take account of any substantiated and likely efficiencies put forward by the undertakings concerned. (Recital 29 ECMR)

\section{Merger is a legal concept provided by company law.}

From Company Law point of view, the cross-border merger is a form of transformation of companies.

Also, merger operations constitute "particular methods of exercise of the freedom of establishment, important for the proper functioning of the internal market, and are therefore amongst those economic activities in respect of which Member States are required to comply with the freedom of establishment laid down by Article 43 EC". (SEVIC Case)

At EU level, the cross-border merger is governed by Directive 2005/56/EC of the European Parliament and of the Council of 26 October 2005 on cross-border mergers of limited liability companies, (so-called the Tenth Directive) and the principles established by CJEU

According to Article 2, para.2 of Tenth Directive, merger is that operation whereby

"a) one or more companies, on being dissolved without going into liquidation, transfer all their assets and liabilities to another existing company, the acquiring company, in exchange for the issue to their members of securities or shares representing the capital of that other company and, if applicable, a cash payment not exceeding $10 \%$ of the nominal value, or, in the absence of a nominal value, of the accounting par value of those securities or shares,

b) two or more companies, on being dissolved without going into liquidation, transfer all their assets and liabilities to a company that they form, the new company, in exchange for the issue to their members of securities or shares representing the capital of that new company and, if applicable, a cash payment not exceeding $10 \%$ of the nominal value, or in the absence of a nominal value, of the accounting par value of those securities or shares; or

c) a company, on being dissolved without going into liquidation, transfers all its assets and liabilities to the company holding all the securities or shares representing its capital."

A transnational merger implies the involvement of the undertakings formed based on at least two different national laws and governed by those laws of different Member States, and also having their registered office, central administration or principal place of business within the Internal Market.

Thus, one of the most important effects of the crossborder merger is change the nationality of the resulting company, without winding up it.
Transnational merger might become the most simple and effective way for companies to move freely around of Internal Market preserving their identity and without interrupting their legal capacity.

\section{Conclusions}

In essence, the cross-border merger is a complex operation with many consequences on the very integrated Internal Market. This situation needs a clear and harmonized legal framework, which covers all the sensitive aspects implied by such transnational merger.

From regional policy point of view, merger may lead to the rationalization of existing undertakings, and a spur for management to perform efficiently. (Easterbrook, Fischel, 1991)

A government may choose to use merger policy as one means of maintaining a balanced distribution of wealth and job opportunities around the country. (Craig, de Burca, 2015)

\section{References}

Bavasso, A. (2005) The role of Intent under Article 82, European Competition Law Review, vol.32, no.1/2005

Berry, E. and Hargreaves, S. (2007), European Union Law, Oxford University Press

Craig, P. and de Burca, G. (2015), EU Law, Text, Cases and Material, Oxford University Press

Easterbrook, F. and Kaplan, R.S. and Fischel, D. (1991), The proper role of a target's management in responding to a tender offer, Harvard Law Review, vol.94, no.2/1991,

Ene, Ch.(2009) Considerations concerning the provisions of European Union Law regarding the merger, research paper presented at the AMIS Conference on June 2009,

Horspool, M. and Humphreys, M. (2006), European Union Law, New York: Oxford University Press

Schindler,C.Ph., (2006), Cross-Border Mergers in Europe -Company Law is catching up! Commentary on the ECJ's Decision in SEVIC Systems AG, 1 ECFR 109/2006,

Stoica,F.C., Ene,Ch., (2016), Business Law Business Organisations, ASE Publishing House, Bucharest,

Law on companies no.31/1990,

Consolidated versions of the Treaty on European Union and the Treaty on the functioning of the European Union, [2010] OJ C-83/47,

Directive 2005/56/EC of the European Parliament and of the Council of 26 October 2005 on cross-border mergers of limited liability companies, (the Tenth Directive) [2005] OJ L-310/1, 
Directive 2009/109/EC of the European Parliament and of the Council of 16 September 2009 amending Council Directives 77/91/EEC, 78/855/EEC and 82/891/EEC, and Directive 2005/56/EC as regards reporting and documentation requirements in the case of mergers and divisions, [2009] OJ L-259/14,

Council Regulation (EC) No 139/2004 of 20 January 2004 on the control of concentrations between undertakings (the EC Merger Regulation) [2004] OJ L24/1.

Communication of the Commission „Financial Services: Implementing the Framework for Financial Markets: Action Plan" COM (1999).

Europemballage Corp. and Continental Can Co.Inc. v. Commission, Case 6/72, ECJ 1973,

United Brands v. Commission, Case 27/76 ECJ 1978

Hoffmann-La Roche, Case 85/76, ECJ 1979

Höfner and Elser Case, C-41/90, ECJ, 1991

SEVIC Case, C-411/03 ECJ, 2005. 